Advertisement

Springer Link

Search Q

- Login

Menu

$\circ$ Login

Search SpringerLink

Search $Q$

- Published: 15 June 2019

\title{
Exploring the role of blended learning for teaching and learning effectiveness in institutions of higher learning: An empirical investigation
}

- Bokolo Anthony Jr $\square$ ORCID: orcid.org/0000-0002-7276-0258눈,

- Adzhar Kamaludin² ,

- Awanis Romli

- Anis Farihan Mat Raffei 2 ,

- Danakorn Nincarean A/L Eh Phon른,

- Aziman Abdullah르,

- Gan Leong Ming $\underline{2}$,

- Nurbiha A. Shukor $\underline{3}$,

- Mohd Shukri Nordin 4 \&

- $[\ldots]$

- Suria Baba

- - Show fewer authors

Education and Information Technologies volume 24, pages3433-3466(2019)Cite this article

- 558 Accesses

- 2 Citations

- $\underline{\text { Metrics details }}$

\section{Abstract}


As the years progress there has been rapid growth in Blended Learning (BL) adoption, but only few research focused on adoption issues related to learners, academic staffs and management. Thus, research is needed to guide universities in strategically examining learners, academic staffs and management adoption of BL. Accordingly, this study develops a model to facilitate university policy makers in their decision making to assess students learning and academic staffs teaching outcome. Furthermore, this study explores on the factors that influence BL adoption in universities, through an empirical study from the perspectives of learners, academic staffs, and management. In particular, it examines the current BL practice adoption effectiveness in universities. Based on extensive review of prior studies, survey questionnaires was designed and distributed to convenience samples of 87 students, academic staffs, and management in 3 Malaysia universities to validate the developed model. Next, Partial Least Square-Structural Equation Modeling (PLS-SEM) was employed to analyze the survey data. Findings reveal that supportive factors, attitude, learning mode, satisfaction, course management, and ease of use positively predict the perception of learners and academic staffs' to adopt BL. Similarly, findings suggest that the perception of management towards BL adoption is positively determined by the strategy, structure, and support factors. Moreover, findings reveal that the impact of BL on learners' effectiveness is positively predicted by achievement, engagement, involvement, retention, and cognitive outcome. Additionally, findings suggest that the impact BL on academic staffs' effectiveness is significantly influence by delivery, performance, evaluation, motivation. Theoretical implications from this study contribute to enhance teaching quality by enriching course management, improving learning content, and facilitate management policies towards effective BL adoption.

This is a preview of subscription content, log in to check access.

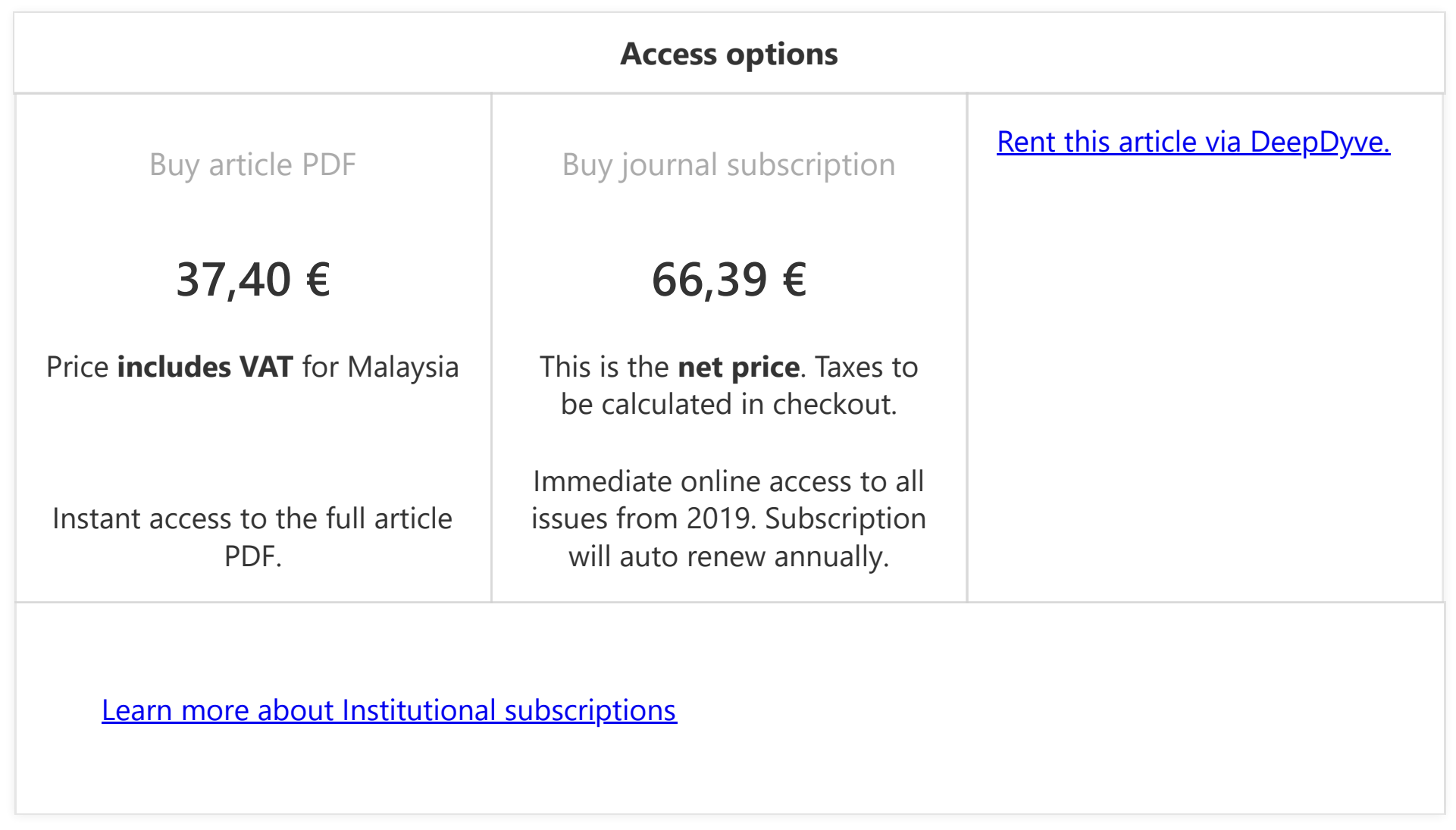

Fig. 1

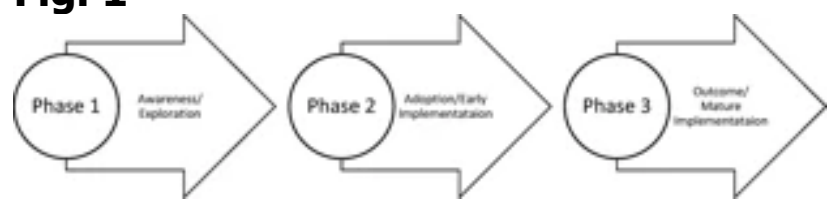


Fig. 2

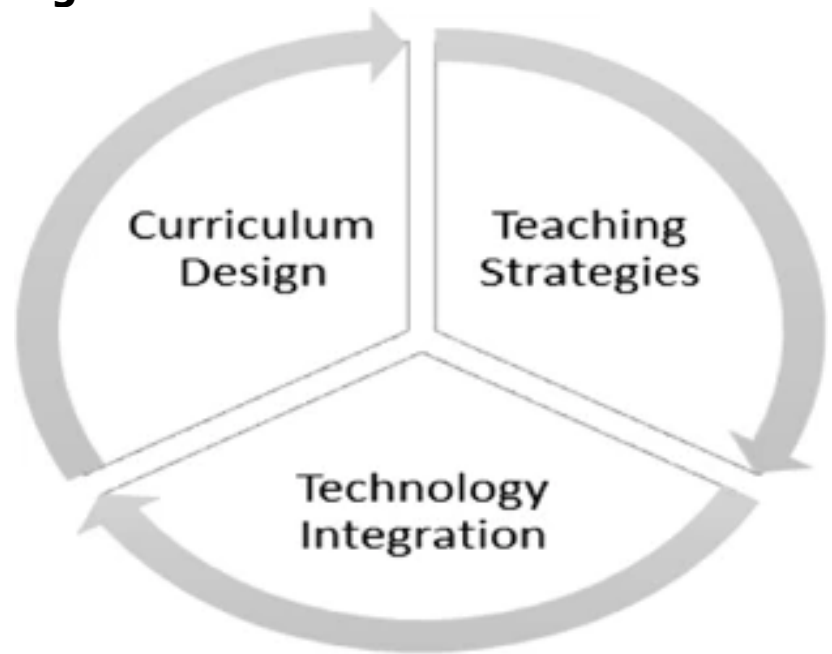

Fig. 3

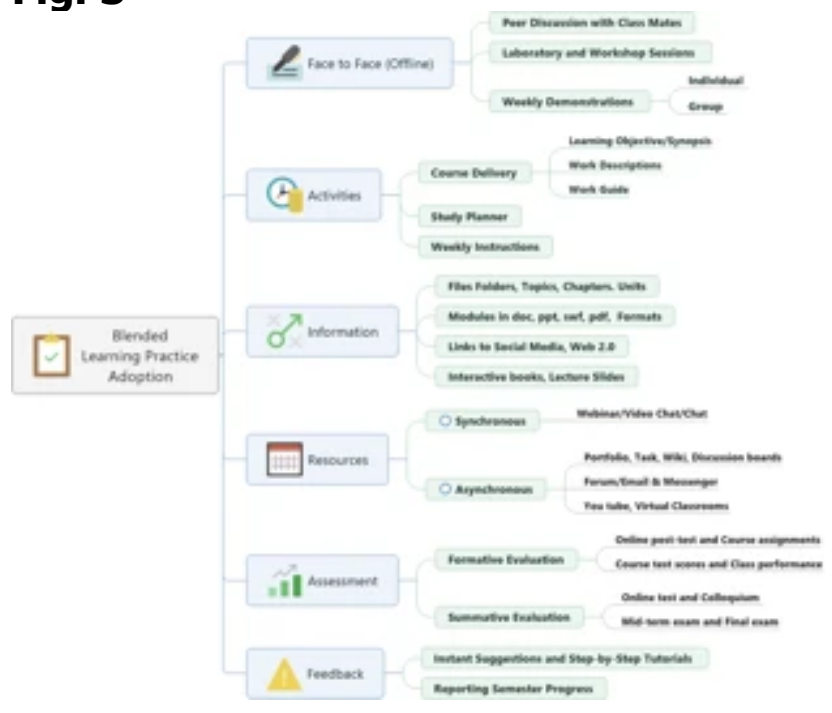

Fig. 4

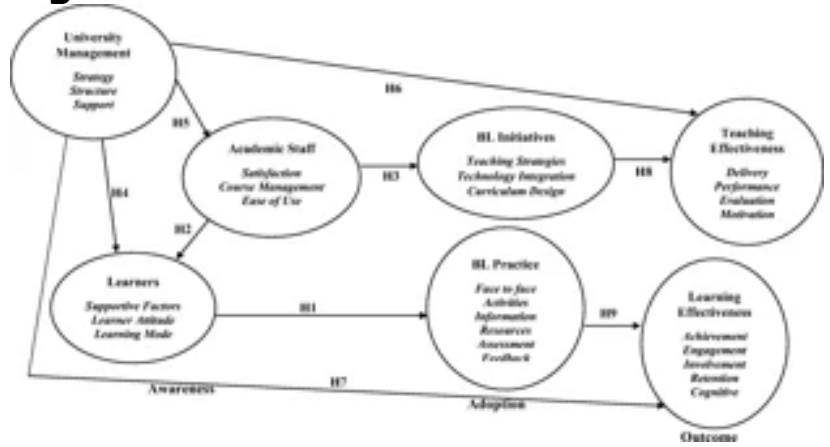

Fig. 5 


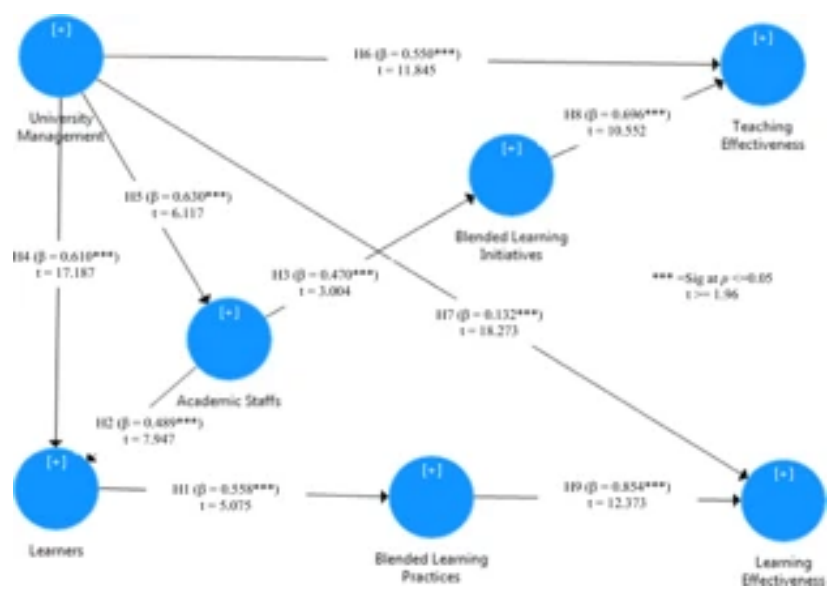

\section{References}

1. Ahmed, H. M. S. (2010). Hybrid E-learning acceptance model: Learner perceptions. Decision Sciences Journal of Innovative Education, 8(2), 313-346.

- Google Scholar

2. Almutairi, F., \& White, S. (2018). How to measure student engagement in the context of blended-MOOC. Interactive Technology and Smart Education, 15(3), 262-278.

- Google Scholar

3. Al-Rahmi, W. M., Alias, N., Othman, M. S., Alzahrani, A. I., Alfarraj, O., Saged, A. A., \& Rahman, N. S. A. (2018). Use of E-learning by university students in Malaysian higher educational institutions: A case in Universiti Teknologi Malaysia. IEEE Access, 6, 14268-14276.

- Google Scholar

4. Al-shami, S. A., Aziz, H., \& Rashid, N. (2019). The adoption of MOOC students in Universiti Teknikal Malaysia Melaka (Utem) utilization among undergraduate. J Fundam Appl Sci., 106S), 2634-2654.

- Google Scholar

5. Anthony, B., Jr. (2019). Green information system integration for environmental performance in organizations: An extension of belief-action-outcome framework and natural resource-based view theory. Benchmarking: An International Journal.

6. Anthony, B., Jr., Abdul Majid, M., \& Romli, A. (2018). A collaborative agent based green IS practice assessment tool for environmental sustainability attainment in enterprise data centers. Journal of Enterprise Information Management, 31(5), 771-795.

- Google Scholar

7. Anthony, B., Majid, M. A., \& Romli, A. (2018). Green IS diffusion in organizations: A model and empirical results from Malaysia. Environment, Development and Sustainability, 1-42.

8. Arbaugh, J. B., Cleveland-Innes, M., Diaz, S. R., Garrison, D. R., Ice, P., Richardson, J. C Swan, K. P. (2008). Developing a community of inquiry instrument: Testing a measure of 
community of inquiry framework using a multi-institutional sample. The Internet and Higher Education, 11(3-4), 133-136.

- Google Scholar

9. BakarNordin, A., \& Alias, N. (2013). Learning outcomes and student perceptions in using of blended learning in history. Procedia-Social and Behavioral Sciences, 103, 577-585.

- Google Scholar

10. Baragash, R. S., \& Al-Samarraie, H. (2018). Blended learning: Investigating the influence of engagement in multiple learning delivery modes on students' performance. Telematics and Informatics, 35(7), 2082-2098.

- Google Scholar

11. Basir, H. M., Ahmad, A., \& Noor, N. L. M. (2010). Institutional strategy for effective blended elearning: HCI perspective of sustainable embedding. i-USEr, 71-76.

12. Bentley, Y., Selassie, H., \& Parkin, E. (2012). Evaluation of a global blended learning MBA programme. The International Journal of Management Education, 10(2), 75-87.

- Google Scholar

13. Bervell, B., \& Umar, I. N. (2018). Blended learning or face-to-face? Does tutor anxiety prevent the adoption of learning management systems for distance education in Ghana? Open Learning: The Journal of Open, Distance and e-Learning, 1-19.

14. Bowyer, J., \& Chambers, L. (2017). Evaluating blended learning: Bringing the elements toghether. Research Matters: A Cambridge Assessment Publication (Vol. 23, pp. 17-26).

- Google Scholar

15. Chang-Tik, C. (2018). Impact of learning styles on the community of inquiry presences in multidisciplinary blended learning environments. Interactive Learning Environments, 26(6), 827-838.

- Google Scholar

16. Chong, S., Cheah, H. M., \& Low, E. L. (2010). Perceptions of student teachers in a blended learning environment. International Journal of Innovation and Learning, 8(4), 345-359.

- Google Scholar

17. Dakduk, S., Santalla-Banderali, Z., \& van der Woude, D. (2018). Acceptance of blended learning in executive education. SAGE Open, 8(3), 215824401880064.

- Google Scholar

18. Deng, R., Benckendorff, P., \& Gannaway, D. (2018). Progress and new directions for teaching and learning in MOOCs. Computers \& Education., 129(1), 48-60.

- Google Scholar 
19. Edward, C. N., Asirvatham, D., \& Johar, M. G. M. (2018). Effect of blended learning and learners' characteristics on students' competence: An empirical evidence in learning oriental music. Education and Information Technologies, 1-20.

20. Fisher, R., Perényi, Á., \& Birdthistle, N. (2018). The positive relationship between flipped and blended learning and student engagement, performance and satisfaction. Active Learning in Higher Education.

21. Fleck, J. (2012). Blended learning and learning communities: Opportunities and challenges. Journal of Management Development, 31(4), 398-411.

- Google Scholar

22. Fornell, C., \& Larcker, D. F. (1981). Evaluating structural equation models with unobservable variables and measurement error. Journal of Marketing Research, 18(1), 39-50.

- Google Scholar

23. Garrison, D. R., \& Kanuka, H. (2004). Blended learning: Uncovering its transformative potential in higher education. The Internet and Higher Education, 72), 95-105.

- Google Scholar

24. Garrison, D. R., \& Vaughan, N. D. (2013). Institutional change and leadership associated with blended learning innovation: Two case studies. The Internet and Higher Education, 18, 24-28.

- Google Scholar

25. Ghazal, S., Aldowah, H., \& Umar, I. (2017). Critical factors to learning management system acceptance and satisfaction in a blended learning environment. Recent Trends in Information and Communication Technology (pp. 688-698). Cham: Springer.

- Google Scholar

26. Ghazal, S., Al-Samarraie, H., \& Aldowah, H. (2018). "I am still learning": Modeling LMS critical success factors for promoting students' experience and satisfaction in a blended learning environment. IEEE Access, 6, 77179-77201.

- Google Scholar

27. Ghazali, R., Soon, C. C., Has, Z., Hassan, S. N. S., \& Hanafi, D. (2018). The effectiveness of blended learning approach with Student's perceptions in control systems engineering course. International Journal of Human and Technology Interaction, 2(2), 103-108.

- Google Scholar

28. Ginns, P., \& Ellis, R. (2007). Quality in blended learning: Exploring the relationships between online and face-to-face teaching and learning. The Internet and Higher Education, 10(1), 53-64.

- Google Scholar

29. Graham, C. R., Woodfield, W., \& Harrison, J. B. (2013). A framework for institutional ador and implementation of blended learning in higher education. The Internet and Higher Ed $18,4-14$. 
- Google Scholar

30. Hair, J. F., et al. (2016). A primer on partial least squares structural equation modeling (PLSSEM). Thousand Oaks: Sage Publications.

- Google Scholar

31. Haron, H., Abbas, W. F., \& Rahman, N. A. A. (2012). The adoption of blended learning among Malaysian academicians. Procedia-Social and Behavioral Sciences, 67, 175-181.

- Google Scholar

32. Ho, W. Y. (2017). A review of blended synchronous learning. International Journal of Social Media and Interactive Learning Environments, 5(4), 278-291.

- Google Scholar

33. Hussin, H., Bunyarit, F., \& Hussein, R. (2009). Instructional design and e-learning: Examining learners' perspective in Malaysian institutions of higher learning. Campus-Wide Information Systems, 26(1), 4-19.

- Google Scholar

34. Jani, J., Muszali, R., Nathan, S., \& Abdullah, M. S. (2018). Blended learning approach using frog Vle platform towards Students'achievement in teaching games for understanding. Journal of Fundamental and Applied Sciences, 10(5S), 1130-1141.

- Google Scholar

35. Ju, S. Y., \& Mei, S. Y. (2018). Perceptions and practices of blended learning in foreign language teaching at USIM. European Journal of Social Sciences Education and Research, 12(1), 170-176.

- Google Scholar

36. Kaur, A., \& Ahmed, A. (2006). E-learning challenges as perceived by communities of practice: Open University Malaysia's experiences. Asian Association of Open Universities Journal, 2(1), 51-65.

- Google Scholar

37. Kaur, M. (2013). Blended learning-its challenges and future. Procedia-Social and Behavioral Sciences, 93, 612-617.

- Google Scholar

38. Klentien, U., \& Wannasawade, W. (2016). Development of blended learning model with virtual science laboratory for secondary students. Procedia-Social and Behavioral Sciences, 217, 706711.

- Google Scholar

39. Koohang, A. (2008). A learner-centred model for blended learning design. International J. of innovation and learning, 6(1), 76-91. 
- Google Scholar

40. Lai, S. Q., Lee, C. L., Yeh, Y. J., \& Ho, C. T. (2005). A study of satisfaction in blended learning for small and medium enterprises. International journal of innovation and learning, 2(3), 319334.

- Google Scholar

41. Liaw, S. S. (2008). Investigating students' perceived satisfaction, behavioral intention, and effectiveness of e-learning: A case study of the blackboard system. Computers \& Education, 51(2), 864-873.

- Google Scholar

42. Lin, W. S., \& Wang, C. H. (2012). Antecedences to continued intentions of adopting e-learning system in blended learning instruction: A contingency framework based on models of information system success and task-technology fit. Computers \& Education, 58(1), 88-99.

- Google Scholar

43. Liqin, Z., Ning, W., \& Chunhui, W. (2015). Construction of a MOOC based blend learning mode. ICCSE, 997-1000.

44. López-Pérez, M. V., Pérez-López, M. C., \& Rodríguez-Ariza, L. (2011). Blended learning in higher education: Students' perceptions and their relation to outcomes. Computers \& Education, 56(3), 818-826.

- Google Scholar

45. Machado, C. (2007). Developing an e-readiness model for higher education institutions: Results of a focus group study. British Journal of Educational Technology, 38(1), 72-82.

- Google Scholar

46. Maulan, S. B., \& Ibrahim, R. (2012). The teaching and learning of English for academic purposes in blended environment. Procedia-Social and Behavioral Sciences, 67, 561-570.

47. McKenzie, W. A., Perini, E., Rohlf, V., Toukhsati, S., Conduit, R., \& Sanson, G. (2013). A blended learning lecture delivery model for large and diverse undergraduate cohorts. Computers \& Education, 64, 116-126.

- Google Scholar

48. Mercado, C. (2008). Readiness assessment tool for an e-learning environment implementation. Special Issue of the International Journal of the Computer, the Internet and Management, 16, $18-11$.

- Google Scholar

49. MOE (2015). Malaysia Education Blueprint 2015-2025 (Higher Education) Executive Summary. Putrajaya: Ministry of Education, Malaysia. available at: https://www.moe.gov.my/index.php/en/dasar/pelan-pembangunan-pendidikan-malaysia/ $\underline{2025}$ (accessed 21 December 2018). 
50. Mohd, I. H., Hussein, N., Aluwi, A. H., \& Omar, M. K. (2016). Enhancing students engagement through blended learning satisfaction and lecturer support. ICEED, 175-180.

51. Mondi, M., Woods, P., \& Rafi, A. (2007). Students"uses and gratification expectancy'conceptual framework in relation to E-learning resources. Asia Pacific Education Review, 8(3), 435-449.

52. Moskal, P., Dziuban, C., \& Hartman, J. (2013). Blended learning: A dangerous idea? The Internet and Higher Education, 18, 15-23.

- Google Scholar

53. Mustapa, M. A. S., Ibrahim, M., \& Yusoff, A. (2015). Engaging vocational college students through blended learning: Improving class attendance and participation. Procedia-Social and Behavioral Sciences, 204, 127-135.

- Google Scholar

54. Naziman, Y. H. N. M., Aznan, N. F. M., Ab Rahman, S. M., Nor, N. H. M., \& Idrus, S. (2018). Fostering the usage of flipped classroom: The conceptual framework. National Academy of Managerial Staff of Culture and Arts Herald, (1), 1189-1194.

55. Nguyen, V. A. (2017). Towards the implementation of an assessment-centred blended learning framework at the course level: A case study in a Vietnamese national university. The International Journal of Information and Learning Technology, 34(1), 20-30.

- Google Scholar

56. Owston, R., York, D., \& Malhotra, T. (2019). Blended learning in large enrolment courses: Student perceptions across four different instructional models. Australasian Journal of Educational Technology, (5), 35.

57. Ozkan, S., \& Koseler, R. (2009). Multi-dimensional students' evaluation of e-learning systems in the higher education context: An empirical investigation. Computers \& Education, 53(4), 12851296.

- Google Scholar

58. Padilla-MeléNdez, A., Del Aguila-Obra, A. R., \& Garrido-Moreno, A. (2013). Perceived playfulness, gender differences and technology acceptance model in a blended learning scenario. Computers \& Education, 63, 306-317.

- Google Scholar

59. Poon, J. (2012). Use of blended learning to enhance the student learning experience and engagement in property education. Property Management, 30(2), 129-156.

- Google Scholar

60. Poon, J. (2014). A cross-country comparison on the use of blended learning in property education. Property Management, 32(2), 154-175.

- Google Scholar 
61. Porter, W. W., \& Graham, C. R. (2016). Institutional drivers and barriers to faculty adoption of blended learning in higher education. British Journal of Educational Technology, 474), 748-762.

- Google Scholar

62. Porter, W. W., Graham, C. R., Bodily, R. G., \& Sandberg, D. S. (2016). A qualitative analysis of institutional drivers and barriers to blended learning adoption in higher education. The Internet and Higher Education, 28, 17-27.

- Google Scholar

63. Prasad, P. W. C., Maag, A., Redestowicz, M., \& Hoe, L. S. (2018). Unfamiliar technology: Reaction of international students to blended learning. Computers \& Education, 122, 92-103.

- Google Scholar

64. Rahman, N. A. A., Hussein, N., \& Aluwi, A. H. (2015). Satisfaction on blended learning in a public higher education institution: What factors matter? Procedia-Social and Behavioral Sciences, 211, 768-775.

- Google Scholar

65. Ramakrisnan, P., Yahya, Y. B., Hasrol, M. N. H., \& Aziz, A. A. (2012). Blended learning: A suitable framework for e-learning in higher education. Procedia-Social and Behavioral Sciences, $67,513-526$.

- Google Scholar

66. Rogers, E. (2003). Diffusion of innovations (5th ed.). New York, NY: Free Press.

- Google Scholar

67. Roszak, M., Kołodziejczak, B., Kowalewski, W., \& Ren-Kurc, A. (2014). Academic blended learning-competences and tools. International Journal of Continuing Engineering Education and Life Long Learning, 24(3-4), 286-301.

- Google Scholar

68. Salloum, S. A., Al-Emran, M., Shaalan, K., \& Tarhini, A. (2019). Factors affecting the E-learning acceptance: A case study from UAE. Education and Information Technologies, 24(1), 509-530.

- Google Scholar

69. Sari, R., \& Karsen, M. (2016). An empirical study on blended learning to improve quality of learning in higher education. ICIMTech, 235-240.

70. Savara, V., \& Parahoo, S. (2018). Unraveling determinants of quality in blended learning: Are there gender-based differences? International Journal of Quality \& Reliability Management, 35(9), 2035-2051.

- Google Scholar

71. Selvi, S. T., \& Perumal, P. (2012). Blended learning for programming in cloud based e-le: system. ICRTIT, 197-201. 
72. Siew-Eng, L., \& Muuk, M. A. (2015). Blended learning in teaching secondary schools' English: A preparation for tertiary science education in Malaysia. Procedia-Social and Behavioral Sciences, $167,293-300$.

- Google Scholar

73. So, H. J., \& Brush, T. A. (2008). Student perceptions of collaborative learning, social presence and satisfaction in a blended learning environment: Relationships and critical factors. Computers \& Education, 51(1), 318-336.

- Google Scholar

74. Spring, K. J., Graham, C. R., \& Hadlock, C. A. (2016). The current landscape of international blended learning. International Journal of Technology Enhanced Learning, 8(1), 84-102.

- Google Scholar

75. Sun, Z., \& Qiu, X. (2017). Developing a blended learning model in an EFL class. International Journal of Continuing Engineering Education and Life Long Learning, 2Х(1-2), 4-21.

- Google Scholar

76. Ta'a, A., Bakar, A., \& Shahbani, M. (2017). Data warehouse system for blended learning in institutions of higher education, e-Academia. Journal, 6(2), 144-155.

- Google Scholar

77. Tahar, N. F., Mokhtar, R., Jaafar, N. H., Zamani, N. D., Sukiman, S. A., \& Ismail, Z. (2013). Students' satisfaction on blended learning: The use of factor analysis. IC3e, 51-56.

78. Wahyuni, S. (2018). The effect of blended learning model towards students' writing ability. Journal Of English For Academic, 5(2), 97-111.

- Google Scholar

79. Wai, C. C., \& Seng, E. L. K. (2015). Measuring the effectiveness of blended learning environment: A case study in Malaysia. Education and Information Technologies, 20(3), 429443.

- Google Scholar

80. Wong, K. T., Hwang, G. J., Choo Goh, P. S., \& Mohd Arrif, S. K. (2018). Effects of blended learning pedagogical practices on students' motivation and autonomy for the teaching of short stories in upper secondary English. Interactive Learning Environments, 1-14.

81. Wong, L., Tatnall, A., \& Burgess, S. (2014). A framework for investigating blended learning effectiveness. Education+ Training, 56(2/3), 233-251.

- Google Scholar

82. Yeou, M. (2016). An investigation of students' acceptance of moodle in a blended learning setting using technology acceptance model. Journal of Educational Technology Systems, 300-318. 
- Google Scholar

83. Yusoff, S., Yusoff, R., \& Md Noh, N. H. (2017). Blended learning approach for less proficient students. SAGE Open, $7(3), 215824401772305$.

- Google Scholar

Download references $\underline{\underline{ }}$

\section{Author information}

\section{Affiliations}

1. Department of Computer Science, Norwegian University of Science and Technology, NTNU, NO7491, Trondheim, Norway

- Bokolo Anthony Jr

2. Universiti Malaysia Pahang, 26300, Gambang, Malaysia

- Adzhar Kamaludin

- , Awanis Romli

- Anis Farihan Mat Raffei

- , Danakorn Nincarean A/L Eh Phon

- , Aziman Abdullah

- \& Gan Leong Ming

3. Universiti Teknologi Malaysia, Johor Bahru, Malaysia

- Nurbiha A. Shukor

4. International Islamic University Malaysia, Selangor, Malaysia

- Mohd Shukri Nordin

5. Universiti Malaysia Kelatan, Kota Bharu, Malaysia

- Suria Baba

Authors

1. Bokolo Anthony Jr

View author publications

You can also search for this author in

- PubMed

- Google Scholar

2. Adzhar Kamaludin

View author publications

You can also search for this author in

- PubMed

- Google Scholar

3. Awanis Romli

View author publications

You can also search for this author in

- PubMed

- Google Scholar

4. Anis Farihan Mat Raffei View author publications

You can also search for this author in

- PubMed 
- Google Scholar

5. Danakorn Nincarean A/L Eh Phon

View author publications

You can also search for this author in

- PubMed

- Google Scholar

6. Aziman Abdullah

View author publications

You can also search for this author in

- PubMed

- Google Scholar

7. Gan Leong Ming

View author publications

You can also search for this author in

- PubMed

- Google Scholar

8. Nurbiha A. Shukor

View author publications

You can also search for this author in

- PubMed

- Google Scholar

9. Mohd Shukri Nordin

View author publications

You can also search for this author in

- PubMed

- Google Scholar

10. Suria Baba

View author publications

You can also search for this author in

- PubMed

- Google Scholar

\title{
Corresponding author
}

Correspondence to Bokolo Anthony Jr.

\section{Additional information}

\section{Publisher's note}

Springer Nature remains neutral with regard to jurisdictional claims in published maps and institutional affiliations.

\section{Rights and permissions}

\author{
$\underline{\text { Reprints and Permissions }}$
}

\section{About this article}


Check for updates

\section{Cite this article}

Anthony, B., Kamaludin, A., Romli, A. et al. Exploring the role of blended learning for teaching and learning effectiveness in institutions of higher learning: An empirical investigation. Educ Inf Technol 24, 3433-3466 (2019). https://doi.org/10.1007/s10639-019-09941-z

\section{Download citation $\underline{\underline{ }}$}

- Received: 27 February 2019

- Accepted: 07 June 2019

- Published: 15 June 2019

- Issue Date: November 2019

- DOII: https://doi.org/10.1007/s10639-019-09941-z

\section{Keywords}

- Institutions of higher learning

- Blended learning

- Teaching effectiveness

- Learning effectiveness

- Partial least square-structural equation modeling

Access options

Buy article PDF

$37,40 €$

Price includes VAT for Malaysia

Instant access to the full article PDF. 
This is the net price. Taxes to be calculated in checkout.

Immediate online access to all issues from 2019.

Subscription will auto renew annually.

\section{$\underline{\text { Rent this article via DeepDyve. }}$}

Learn more about Institutional subscriptions

- Sections

- Figures

- References

- Abstract

- References

- Author information

- Additional information

- Rights and permissions

- About this article

Advertisement

- $\quad$ Fig. 1

- $\quad$ Fig. 2

- $\quad$ Fig. 3

- $\quad$ Fig. 4

- $\quad$ Fig. 5

1. Ahmed, H. M. S. (2010). Hybrid E-learning acceptance model: Learner perceptions. Decision Sciences Journal of Innovative Education, 8(2), 313-346.

- Google Scholar

2. Almutairi, F., \& White, S. (2018). How to measure student engagement in the context of 
blended-MOOC. Interactive Technology and

Smart Education, 15(3), 262-278.

- Google Scholar

3. Al-Rahmi, W. M., Alias, N., Othman, M. S., Alzahrani, A. I., Alfarraj, O., Saged, A. A., \& Rahman, N. S. A. (2018). Use of E-learning by university students in Malaysian higher educational institutions: A case in Universiti Teknologi Malaysia. IEEE Access, 6, 1426814276.

- Google Scholar

4. Al-shami, S. A., Aziz, H., \& Rashid, N. (2019). The adoption of MOOC students in Universiti Teknikal Malaysia Melaka (Utem) utilization among undergraduate. J Fundam App/ Sci., 10(6S), 2634-2654.

- Google Scholar

5. Anthony, B., Jr. (2019). Green information system integration for environmental performance in organizations: An extension of belief-action-outcome framework and natural resource-based view theory. Benchmarking: An International Journal.

6. Anthony, B., Jr., Abdul Majid, M., \& Romli, A. (2018). A collaborative agent based green IS practice assessment tool for environmental sustainability attainment in enterprise data centers. Journal of Enterprise Information Management, 31(5), 771-795.

- Google Scholar

7. Anthony, B., Majid, M. A., \& Romli, A. (2018). Green IS diffusion in organizations: A model and empirical results from Malaysia. Environment, Development and Sustainability, 1-42.

8. Arbaugh, J. B., Cleveland-Innes, M., Diaz, S. R., Garrison, D. R., Ice, P., Richardson, J. C., \& Swan, K. P. (2008). Developing a community of inquiry instrument: Testing a measure of the community of inquiry framework using a multiinstitutional sample. The Internet and Higher Education, 11(3-4), 133-136.

- Google Scholar 
9. BakarNordin, A., \& Alias, N. (2013). Learning outcomes and student perceptions in using of blended learning in history. Procedia-Social and Behavioral Sciences, 103, 577-585.

- Google Scholar

10. Baragash, R. S., \& Al-Samarraie, H. (2018). Blended learning: Investigating the influence of engagement in multiple learning delivery modes on students' performance. Telematics and Informatics, 35(7), 2082-2098.

- Google Scholar

11. Basir, H. M., Ahmad, A., \& Noor, N. L. M. (2010). Institutional strategy for effective blended elearning: $\mathrm{HCI}$ perspective of sustainable embedding. i-USEr, 71-76.

12. Bentley, Y., Selassie, H., \& Parkin, E. (2012). Evaluation of a global blended learning MBA programme. The International Journal of Management Education, 10(2), 75-87.

- Google Scholar

13. Bervell, B., \& Umar, I. N. (2018). Blended learning or face-to-face? Does tutor anxiety prevent the adoption of learning management systems for distance education in Ghana? Open Learning: The Journal of Open, Distance and eLearning, 1-19.

14. Bowyer, J., \& Chambers, L. (2017). Evaluating blended learning: Bringing the elements toghether. Research Matters: A Cambridge Assessment Publication (Vol. 23, pp. 17-26).

- Google Scholar

15. Chang-Tik, C. (2018). Impact of learning styles on the community of inquiry presences in multidisciplinary blended learning environments. Interactive Learning Environments, 26(6), 827838.

- Google Scholar

16. Chong, S., Cheah, H. M., \& Low, E. L. (2010). Perceptions of student teachers in a blended learning environment. International Journal of Innovation and Learning, 8(4), 345-359. 
- Google Scholar

17. Dakduk, S., Santalla-Banderali, Z., \& van der Woude, D. (2018). Acceptance of blended learning in executive education. SAGE Open, $8(3), 215824401880064$.

- Google Scholar

18. Deng, R., Benckendorff, P., \& Gannaway, D. (2018). Progress and new directions for teaching and learning in MOOCs. Computers \& Education., $129(1), 48-60$.

- Google Scholar

19. Edward, C. N., Asirvatham, D., \& Johar, M. G. M. (2018). Effect of blended learning and learners' characteristics on students' competence: An empirical evidence in learning oriental music. Education and Information Technologies, 1-20.

20. Fisher, R., Perényi, Á., \& Birdthistle, N. (2018). The positive relationship between flipped and blended learning and student engagement, performance and satisfaction. Active Learning in Higher Education.

21. Fleck, J. (2012). Blended learning and learning communities: Opportunities and challenges. Journal of Management Development, 31(4), 398-411.

- Google Scholar

22. Fornell, C., \& Larcker, D. F. (1981). Evaluating structural equation models with unobservable variables and measurement error. Journal of Marketing Research, 18(1), 39-50.

- Google Scholar

23. Garrison, D. R., \& Kanuka, H. (2004). Blended learning: Uncovering its transformative potential in higher education. The Internet and Higher Education, 72), 95-105.

- Google Scholar

24. Garrison, D. R., \& Vaughan, N. D. (2013). Institutional change and leadership associated with blended learning innovation: Two case 
studies. The Internet and Higher Education, 18,

24-28.

- Google Scholar

25. Ghazal, S., Aldowah, H., \& Umar, I. (2017). Critical factors to learning management system acceptance and satisfaction in a blended learning environment. Recent Trends in Information and Communication Technology (pp. 688-698). Cham: Springer.

- Google Scholar

26. Ghazal, S., Al-Samarraie, H., \& Aldowah, H. (2018). "I am still learning": Modeling LMS critical success factors for promoting students' experience and satisfaction in a blended learning environment. IEEE Access, 6, 77179-77201.

- Google Scholar

27. Ghazali, R., Soon, C. C., Has, Z., Hassan, S. N. S., \& Hanafi, D. (2018). The effectiveness of blended learning approach with Student's perceptions in control systems engineering course. International Journal of Human and Technology Interaction, 2(2), 103-108.

- Google Scholar

28. Ginns, P., \& Ellis, R. (2007). Quality in blended learning: Exploring the relationships between online and face-to-face teaching and learning. The Internet and Higher Education, 10(1), 53-64.

- Google Scholar

29. Graham, C. R., Woodfield, W., \& Harrison, J. B. (2013). A framework for institutional adoption and implementation of blended learning in higher education. The Internet and Higher Education, 18, 4-14.

- Google Scholar

30. Hair, J. F., et al. (2016). A primer on partial least squares structural equation modeling (PLS-SEM). Thousand Oaks: Sage Publications.

- Google Scholar 
31. Haron, H., Abbas, W. F., \& Rahman, N. A. A. (2012). The adoption of blended learning among Malaysian academicians. Procedia-Social and Behavioral Sciences, 67, 175-181.

- Google Scholar

32. Ho, W. Y. (2017). A review of blended synchronous learning. International Journal of Social Media and Interactive Learning Environments, 5(4), 278-291.

- Google Scholar

33. Hussin, H., Bunyarit, F., \& Hussein, R. (2009). Instructional design and e-learning: Examining learners' perspective in Malaysian institutions of higher learning. Campus-Wide Information Systems, 26(1), 4-19.

- Google Scholar

34. Jani, J., Muszali, R., Nathan, S., \& Abdullah, M. S. (2018). Blended learning approach using frog Vle platform towards Students'achievement in teaching games for understanding. Journal of Fundamental and Applied Sciences, 10(5S), 1130-1141.

- Google Scholar

35. Ju, S. Y., \& Mei, S. Y. (2018). Perceptions and practices of blended learning in foreign language teaching at USIM. European Journal of Social Sciences Education and Research, 12(1), 170176.

- Google Scholar

36. Kaur, A., \& Ahmed, A. (2006). E-learning challenges as perceived by communities of practice: Open University Malaysia's experiences. Asian Association of Open Universities Journal, 2(1), 51-65.

- Google Scholar

37. Kaur, M. (2013). Blended learning-its challenges and future. Procedia-Social and Behavioral Sciences, 93, 612-617.

- Google Scholar 
38. Klentien, U., \& Wannasawade, W. (2016).

Development of blended learning model with virtual science laboratory for secondary students. Procedia-Social and Behavioral Sciences, 217, 706-711.

- Google Scholar

39. Koohang, A. (2008). A learner-centred model for blended learning design. International Journal of innovation and learning, 6(1), 76-91.

- Google Scholar

40. Lai, S. Q., Lee, C. L., Yeh, Y. J., \& Ho, C. T. (2005). A study of satisfaction in blended learning for small and medium enterprises. International journal of innovation and learning, 2(3), 319-334.

- Google Scholar

41. Liaw, S. S. (2008). Investigating students' perceived satisfaction, behavioral intention, and effectiveness of e-learning: A case study of the blackboard system. Computers \& Education, 51(2), 864-873.

- Google Scholar

42. Lin, W. S., \& Wang, C. H. (2012). Antecedences to continued intentions of adopting e-learning system in blended learning instruction: A contingency framework based on models of information system success and task-technology fit. Computers \& Education, 58(1), 88-99.

- Google Scholar

43. Liqin, Z., Ning, W., \& Chunhui, W. (2015). Construction of a MOOC based blend learning mode. ICCSE, 997-1000.

44. López-Pérez, M. V., Pérez-López, M. C., \& Rodríguez-Ariza, L. (2011). Blended learning in higher education: Students' perceptions and their relation to outcomes. Computers \& Education, 56(3), 818-826.

- Google Scholar

45. Machado, C. (2007). Developing an e-readiness model for higher education institutions: Results 
of a focus group study. British Journal of

Educational Technology, 38(1), 72-82.

- Google Scholar

46. Maulan, S. B., \& Ibrahim, R. (2012). The teaching and learning of English for academic purposes in blended environment. ProcediaSocial and Behavioral Sciences, 67, 561-570.

47. McKenzie, W. A., Perini, E., Rohlf, V., Toukhsati, S., Conduit, R., \& Sanson, G. (2013). A blended learning lecture delivery model for large and diverse undergraduate cohorts. Computers \& Education, 64, 116-126.

- Google Scholar

48. Mercado, C. (2008). Readiness assessment tool for an e-learning environment implementation. Special Issue of the International Journal of the Computer, the Internet and Management, 16, 18-11.

- Google Scholar

49. MOE (2015). Malaysia Education Blueprint 20152025 (Higher Education) Executive Summary. Putrajaya: Ministry of Education, Malaysia. available at:

https://www.moe.gov.my/index.php/en/dasar/pelanpembangunan-pendidikan-malaysia-2013-2025 (accessed 21 December 2018).

50. Mohd, I. H., Hussein, N., Aluwi, A. H., \& Omar, M. K. (2016). Enhancing students engagement through blended learning satisfaction and lecturer support. ICEED, 175-180.

51. Mondi, M., Woods, P., \& Rafi, A. (2007). Students"uses and gratification expectancy'conceptual framework in relation to E-learning resources. Asia Pacific Education Review, 8(3), 435-449.

52. Moskal, P., Dziuban, C., \& Hartman, J. (2013). Blended learning: A dangerous idea? The Internet and Higher Education, 18, 15-23.

- Google Scholar

53. Mustapa, M. A. S., Ibrahim, M., \& Yusoff, A. (2015). Engaging vocational college students 
through blended learning: Improving class attendance and participation. Procedia-Social and Behavioral Sciences, 204, 127-135.

- Google Scholar

54. Naziman, Y. H. N. M., Aznan, N. F. M., Ab Rahman, S. M., Nor, N. H. M., \& Idrus, S. (2018). Fostering the usage of flipped classroom: The conceptual framework. National Academy of Managerial Staff of Culture and Arts Herald, (1), 1189-1194.

55. Nguyen, V. A. (2017). Towards the implementation of an assessment-centred blended learning framework at the course level: A case study in a Vietnamese national university. The International Journal of Information and Learning Technology, 34(1), 20-30.

- Google Scholar

56. Owston, R., York, D., \& Malhotra, T. (2019). Blended learning in large enrolment courses: Student perceptions across four different instructional models. Australasian Journal of Educational Technology, (5), 35.

57. Ozkan, S., \& Koseler, R. (2009). Multidimensional students' evaluation of e-learning systems in the higher education context: An empirical investigation. Computers \& Education, 53(4), 1285-1296.

- Google Scholar

58. Padilla-MeléNdez, A., Del Aguila-Obra, A. R., \& Garrido-Moreno, A. (2013). Perceived playfulness, gender differences and technology acceptance model in a blended learning scenario. Computers \& Education, 63, 306-317.

- Google Scholar

59. Poon, J. (2012). Use of blended learning to enhance the student learning experience and engagement in property education. Property Management, 30(2), 129-156.

- Google Scholar

60. Poon, J. (2014). A cross-country comparison on the use of blended learning in property 
education. Property Management, 32(2), 154-

175.

- Google Scholar

61. Porter, W. W., \& Graham, C. R. (2016). Institutional drivers and barriers to faculty adoption of blended learning in higher education. British Journal of Educational Technology, 4ス4), 748-762.

- Google Scholar

62. Porter, W. W., Graham, C. R., Bodily, R. G., \& Sandberg, D. S. (2016). A qualitative analysis of institutional drivers and barriers to blended learning adoption in higher education. The Internet and Higher Education, 28, 17-27.

- Google Scholar

63. Prasad, P. W. C., Maag, A., Redestowicz, M., \& Hoe, L. S. (2018). Unfamiliar technology:

Reaction of international students to blended learning. Computers \& Education, 122, 92-103.

- Google Scholar

64. Rahman, N. A. A., Hussein, N., \& Aluwi, A. H. (2015). Satisfaction on blended learning in a public higher education institution: What factors matter? Procedia-Social and Behavioral Sciences, 211, 768-775.

- Google Scholar

65. Ramakrisnan, P., Yahya, Y. B., Hasrol, M. N. H., \& Aziz, A. A. (2012). Blended learning: A suitable framework for e-learning in higher education. Procedia-Social and Behavioral Sciences, 67, 513-526.

- Google Scholar

66. Rogers, E. (2003). Diffusion of innovations (5th ed.). New York, NY: Free Press.

- Google Scholar

67. Roszak, M., Kołodziejczak, B., Kowalewski, W., \& Ren-Kurc, A. (2014). Academic blended learning-competences and tools. International 
Journal of Continuing Engineering Education and Life Long Learning, 24(3-4), 286-301.

- Google Scholar

68. Salloum, S. A., Al-Emran, M., Shaalan, K., \& Tarhini, A. (2019). Factors affecting the Elearning acceptance: A case study from UAE. Education and Information Technologies, 24(1), 509-530.

- Google Scholar

69. Sari, R., \& Karsen, M. (2016). An empirical study on blended learning to improve quality of learning in higher education. ICIMTech, 235240.

70. Savara, V., \& Parahoo, S. (2018). Unraveling determinants of quality in blended learning: Are there gender-based differences? International Journal of Quality \& Reliability Management, 35(9), 2035-2051.

- Google Scholar

71. Selvi, S. T., \& Perumal, P. (2012). Blended learning for programming in cloud based elearning system. ICRTIT, 197-201.

72. Siew-Eng, L., \& Muuk, M. A. (2015). Blended learning in teaching secondary schools' English: A preparation for tertiary science education in Malaysia. Procedia-Social and Behavioral Sciences, 167, 293-300.

- Google Scholar

73. So, H. J., \& Brush, T. A. (2008). Student perceptions of collaborative learning, social presence and satisfaction in a blended learning environment: Relationships and critical factors. Computers \& Education, 51(1), 318-336.

- Google Scholar

74. Spring, K. J., Graham, C. R., \& Hadlock, C. A. (2016). The current landscape of international blended learning. International Journal of Technology Enhanced Learning, 8(1), 84-102.

- Google Scholar 
75. Sun, Z., \& Qiu, X. (2017). Developing a blended learning model in an EFL class. International Journal of Continuing Engineering Education and Life Long Learning, 27(1-2), 4-21.

- Google Scholar

76. Ta'a, A., Bakar, A., \& Shahbani, M. (2017). Data warehouse system for blended learning in institutions of higher education, e-Academia. Journal, 6(2), 144-155.

- Google Scholar

77. Tahar, N. F., Mokhtar, R., Jaafar, N. H., Zamani, N. D., Sukiman, S. A., \& Ismail, Z. (2013). Students' satisfaction on blended learning: The use of factor analysis. IC3e, 51-56.

78. Wahyuni, S. (2018). The effect of blended learning model towards students' writing ability. Journal Of English For Academic, 5(2), 97-111.

- Google Scholar

79. Wai, C. C., \& Seng, E. L. K. (2015). Measuring the effectiveness of blended learning environment: A case study in Malaysia.

Education and Information Technologies, 20(3), 429-443.

- Google Scholar

80. Wong, K. T., Hwang, G. J., Choo Goh, P. S., \& Mohd Arrif, S. K. (2018). Effects of blended learning pedagogical practices on students' motivation and autonomy for the teaching of short stories in upper secondary English. Interactive Learning Environments, 1-14.

81. Wong, L., Tatnall, A., \& Burgess, S. (2014). A framework for investigating blended learning effectiveness. Education+ Training, 56(2/3), 233-251.

- Google Scholar

82. Yeou, M. (2016). An investigation of students' acceptance of moodle in a blended learning setting using technology acceptance model. Journal of Educational Technology Systems, 44(3), 300-318. 
- Google Scholar

83. Yusoff, S., Yusoff, R., \& Md Noh, N. H. (2017).

Blended learning approach for less proficient

students. SAGE Open, 73), 215824401772305.

- Google Scholar

Over 10 million scientific documents at your fingertips

\section{Switch Edition}

- Academic Edition

- Corporate Edition

- Home

- Impressum

- Legal information

- Privacy statement

- How we use cookies

- Accessibility

- $\underline{\text { Contact us }}$

Not logged in - 60.54.43.79

Not affiliated

Springer Nature SPRINGER NATURE

(C) 2020 Springer Nature Switzerland AG. Part of Springer Nature. 